\title{
Effects of Smoking on Acute Hypobaric Hypoxia Tolerance
}

\section{Sigara Kullanımının Akut Hipobarik Hipoksi Toleransı Üzerine Etkisi}

\author{
๑ Erdinç $\operatorname{Ercan}^{1}$, ๑ Menduh Şavaş İlbasmış², • Cantürk Taşçı ${ }^{3}$ \\ ${ }^{1}$ Health Science University, Department of Aerospace Medicine, Ankara, Turkey \\ ${ }^{2}$ Yunus Emre State Hospital, Clinic of Hyperbaric Oxygen Therapy, Eskişehir, Turkey \\ ${ }^{3}$ Health Science University, Department of Pulmonology, Ankara, Turkey
}

Background: Smoking may impair oxygen transport ability of blood and airway destructions might be seen in long term smokers. After 1-3 cigarette smoking, it leads to a rise in carboxyhemoglobin level in blood, and it has a negative effect such as taking extra $5,000-8,000$ feet altitude. Thus, it is thought that smoking before or in-flight may contribute to altitude hypoxia. The objective of this study was to evaluate the effects of smoking on acute hypobaric hypoxia tolerance at 30,000 ft. simulated altitude.

Materials and Methods: This study was planned prospectively, and a standardized survey that consisted of smoking status and demographic characteristics of subjects was applied before the procedures. Aircrews are exposed to high altitude during "Hypobaric Hypoxia Training" in an altitude chamber. Pulse oximeter measurements were done to analyze oxygen saturations during different stages of the hypoxia trainings.

Results: Seventy eight male healthy aircrews were included in this study. Twenty five (32.1\%) of subjects stated that they were currently smoking (4.9 \pm 2.6 years). Hypoxic pulse oximeter mean values of the Nonsmoker Group were higher than those of the Smoker Group ( $p>0.05$ ). The three most frequently checked symptoms were numbness, tingling and perspiration among all participants. Flushing was the most frequent symptom in the Smoker Group while numbness was the most frequent symptom in the Nonsmoker Group. Both early and late symptoms among pilots were higher in the Smoker Group ( $p>0.05)$. More symptoms were checked among smokers during hypoxia exposure in this study $(\mathrm{p}>0.05)$.

Conclusion: Our results might be attributed to hypoxia sensitiveness of smokers, and the use of tobacco products by aviation personnel was considered to be disadvantage in aviation environment. Because of this, doctors who carry out aviation examinations and practise preventive medicine in aviation field should be aware of the importance of this issue. The influences of carboxyhemoglobin on hypoxia tolerance might be better observed at lower altitudes if this study would have been redone at 18,000 and 25,000 simulated altitudes.

Keywords: hypobaric hypoxia training, smoking, altitude tolerance, hypoxia tolerance

Amaç: Sigara kullanımı kanda oksijen transportunu bozduğu gibi uzun dönem kullanımında solunum yolu harabiyetine neden olur. Bir ile üç arasında sigara içimi kanda karboksihemoglobin seviyelerini artııır ve 5.000-8.000 ft. daha yüksek irtifada bulunuyormuş gibi negatif bir etki oluşturur. Böylece, uçuştan hemen önce veya uçuş sırasında sigara içilmesi irtifa hipoksisini arttırabilir. Bu çalışmanın amacı 30.000 ft. simüle irtifada oluşan hipobarik hipoksi toleransına sigara kullanımının etkilerinin değerlendirilmesidir.

Gereç ve Yöntemler: Prospektif planlanan bu çalışmaya başlanmadan önce kişilerin demografik özelliklerini ve sigara kullanım durumlarını sorgulayan bir anket çalışması uygulandı. İrtifa odasında icra edilen hipobarik hipoksi eğitimi sırasında havacılık personelleri yüksek irtifaya maruz kalmaktadırlar. Çalışmamızda, hipoksi eğitiminin çeşitli safhalarında kan oksijen satürasyon değişimlerinin analizi için pulse oksimetre ölçümleri yapıımışve ölçüm sonuçları sigara kullanım durumlarına göre karşılaştırılmıştır. Bulgular: Bu çalışmaya 78 sağıkı erkek havacılık personeli dahil edildi. Katılımcılardan 25’i (\%32,1) sigara kullandığını belirtmiştir (4,9 2,6 yıl). Sigara kullanmayanların hipoksik pulse oksimetre ortalamaları sigara kullananlara göre yüksek bulunmuştur ( $p>0,05)$. Tüm katılımcılar arasında en sık işaretlenmiş olan üç semptom uyuşma, karıncalanma ve terlemedir. Sigara kullanan grupta en sık işaretlenen semptom ateş basması iken sigara içmeyen grupta en sık işaretlenen bulgu uyuşma olmuştur. Katılımcılar arasında

Address for Correspondence: Erdinç Ercan, Health Science University, Department of Aerospace Medicine, Ankara, Turkey Phone: +90 5413677976 E-mail: drerdincercan@gmail.com ORCID ID: orcid.org/0000-0002-4478-7031

Received: 02.03.2021 Accepted: 26.03.2021 
hem erken hem de geç hipoksi semptomları sigara içen grupta daha fazla bulunmuştur ( $p>0,05)$. Bu çalışmada hipoksi maruziyeti sırasında sigara içenler daha fazla semptom işaretlemiştir $(p>0,05)$.

Sonuç: Bizim sonuçlarımız sigara kullananların irtifa hipoksisine daha duyarlı olduğunu düşündürmektedir. Diğer taraftan havacılık personelinde sigara kullanımı sıklığının normal popülasyona benzerlik göstermesinden ötürü sigara kullanımı havacılık ortamında dezavantaj olarak kabul edilebilir. Bu nedenle, havacılık muayenelerini gerçekleştiren ve havacılık alanında koruyucu hekimlik icra eden doktorların bu durumun öneminin farkında olması gerekmektedir. Karboksihemoglobinin hipoksi toleransına etkileri daha düşük irtifalarda daha iyi gözlemlenebilir ve bu çalışmanın $18.000 \mathrm{ft}$. ve $25.000 \mathrm{ft}$. simüle irtifalarda tekrarlanması ile istatistiksel anlamlı sonuçlar elde edilebilir.

Anahtar Kelimeler: hipobarik hipoksi eğitimi, sigara kullanımı, yüksek irtifa toleransı, hipoksi toleransı

\section{Introduction}

There are four types of hypoxia. Respiratory problems or scarcity of the oxygen impair alveolocapillary diffusion and lead to hypoxic or hypobaric hypoxia. Transport deficiencies of the oxygen or the blood to the tissues lead to Hypemic or stagnant hypoxia. When utilization of the oxygen in the cells is degraded, it is called histotoxic hypoxia. Acute hypoxia in aviation is generally caused by low partial oxygen pressure $\left(\mathrm{PO}_{2}\right)$ at high altitudes. Hypoxia impairs consciousness and psychomotor functions of the aviators and risks aviation safety.

It is thought that respiratory function impairments and airway destructions, as is seen in long term smokers or in many diseases of respiratory system, may contribute to hypoxia. Smoking before or in-flight may impair oxygen transport ability of blood. After 1-3 cigarette smoking, it leads to a rise in carboxyhemoglobin level in blood, and it has a negative effect such as taking extra 5,000-8,000 feet altitude $(1,2)$. So, this is expected to reduce hypoxia tolerance of the aviation personnel.

The objective of this study was to evaluate the effects of smoking on acute hypobaric hypoxia tolerance at 30,000 feet simulated altitude.

\section{Material and Methods}

\section{Research Design}

This study was planned prospectively, and subjects were fully informed about the procedure and written consent was taken. Each stage of the research was carried out based on the Declaration of Helsinki, and the Committee of Clinical Research Ethics approved the study (Number: 1491-126811/1539, Date: 21/02/2011). A standardized survey that consisted of smoking status and demographic characteristics of subjects was applied before the procedures.

After routine medical examinations, aircrew are enrolled in the aerospace physiology trainings. One of these trainings is "Hypobaric Hypoxia Training" and in this training, aircrews are exposed to 30,000 feet altitude equivalent hypobaric environment in an altitude chamber. Ten aircrews attend hypoxia training in one session and experience hypoxia to learn counter measures. Hypobaric hypoxia training starts with 30 minutes of $100 \%$ oxygen pre-breathe for denitrogenation via tight fitted oronasal aviation mask. After denitrogenation, immediate ascend and descent to/from 5,000 feet simulated altitude procedure is performed for any possible barotrauma problem before the procedure that is called "sinus check". Unless any ear or sinus barotraumas do not occur in any of trainees, ascending continues until the 30,000 feet simulated altitude $(5,000 \mathrm{feet} / \mathrm{min}$ climb rate) is reached. Inside chamber, operators breathe $100 \% \mathrm{O}_{2}$ during all phases of the training while trainees breathe $100 \% \mathrm{O}_{2}$ in all phases of the training except hypobaric hypoxia test period (Figure 1).

At the training altitude, 2 or 3 trainees take off their masks and start solving provided hypoxia test sheet while the other trainees observe the hypoxia training. The hypoxia training is terminated when the trainees become succumb or pulse oximeter value $\left(\mathrm{SpO}_{2}\right)$ decrease to $60 \%$. Inside operator puts the trainees' oxygen mask on unless trainees recognize hypoxia and recover by themselves.

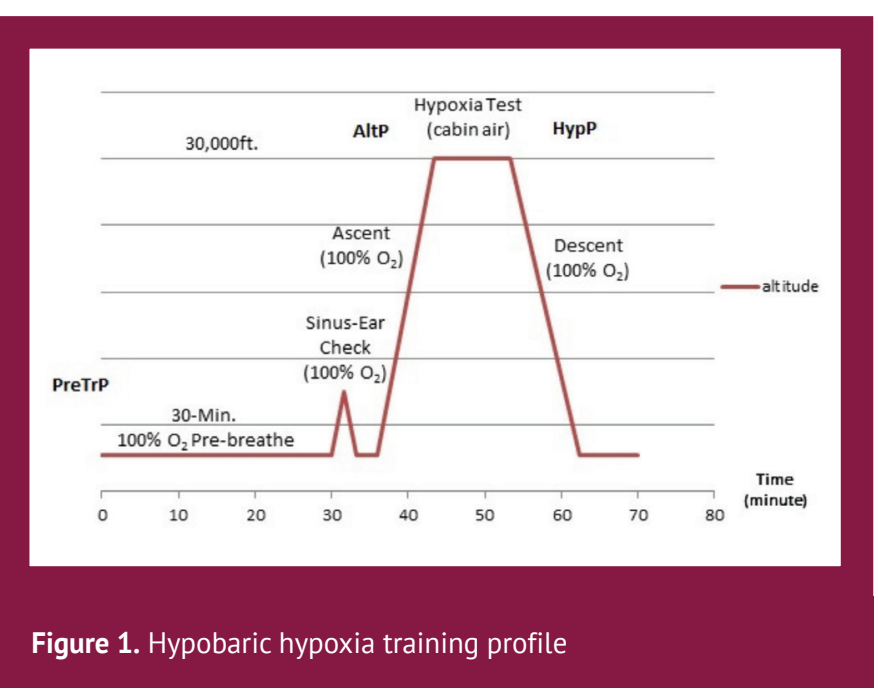




\section{Subjects}

Aircrews who were admitted to physiological trainings were in the same medical and physical standards as they had the similar education. All subjects passed aero-medical examination and had the medical report of "fit to fly" before the physiological trainings.

\section{Procedure}

We used noninvasive pulse oximeter to analyze the blood oxygen saturation changes of the subjects during different stages of the hypoxia training. First pulse oximetry measurements (PreTrP) were performed before the training, second measurements (AltP) were performed at training altitude before taking off the oxygen masks, and last measurements (HypP) were done at training altitude after hypoxia test before mask on (Figure 1). We used point merging puzzles for hypoxia test. During the hypoxia test, subjects completed the first puzzle in approximately one minute and they checked or wrote the early symptoms that they felt at that moment below the first puzzle. Later trainees continued to the second puzzle and checked or wrote late symptoms that they felt at that moment below the second puzzle (Figure 2).

\section{Statistical Analysis}

The study data were edited in Microsoft ${ }^{\circledR}$ Excel software and Statistical analysis was performed in SPSS ${ }^{\circledR}$ data analysis software. The KolmogorovSmirnov normality test was used for all parameters. The Independent Samples t-test or Mann-Whitney U test was used in between-groups analyses, and the Paired t-test or the Wilcoxon t-test was used in within-group (Pre/Post exposure) analyses. The chi-square test and Fischer's Exact test were also executed for statistical significance. A value of $p<0.05$ was considered to be statistically significant.

\section{Results}

Eighty eight male aircrews were admitted to physiological trainings. A total of 10 subjects were excluded from the study because 2 trainees did not properly fill or return the questionnaire, 3 in-flight medical events (2 emesis, 1 epistaxis) led to the cancelation of hypoxia training sessions of 5 more trainees.

So, seventy eight male healthy pilot aircrews whose ages varied between 21 and 24 years (mean: 22.53 \pm 0.6 ) were included in this study. Their heights were ranged between $170 \mathrm{~cm}$ and $194 \mathrm{~cm}$ (mean: $178.83 \mathrm{~cm} \pm 5.2$ ) and weights ranged between $56 \mathrm{~kg}$ and $98 \mathrm{~kg}$ (mean: 72.83 7.7). Body mass index values were calculated and ranged between 17.28 and 28.39 (mean: $22.75 \pm 1.9$ ).
In this study, smoking status of the subjects was questioned and 25 (32.1\%) of 78 subjects stated that they were currently smoking (4.9 \pm 2.6 years). Study results were grouped according to smoking status and presented in Table 1. During training, Hypoxic Pulse values of the Nonsmoker Group were higher than those of the Smoker Group, but it was statistically insignificant $(p>0.05)$. Other results were very close in both groups ( $p>0.05$ ) (Table 1$)$.

All subjects completed the first puzzle that took about one minute for each subject to solve. Four subjects in Smokers' Group (SMK) and five subjects in Non-SMK could not complete the second puzzle and did not check the symptom they felt at that moment. When we analyzed these nine subjects who did not check late symptoms, three of them were in SMK and four of them were in Non-SMK who already checked early symptoms.

The three most frequently checked symptoms were numbness, tingling and perspiration among all participants. The symptoms that were widely checked by the subjects in SMK at early phase were flushing, perspiration, numbness, visual disturbances, and headache. Additionally, frequently reported symptoms in SMK participants at the late phase were numbness, dizziness, flushing and tingling. The symptoms that the Non-SMK mostly checked at the early phase were dizziness, numbness, perspiration, and tingling.

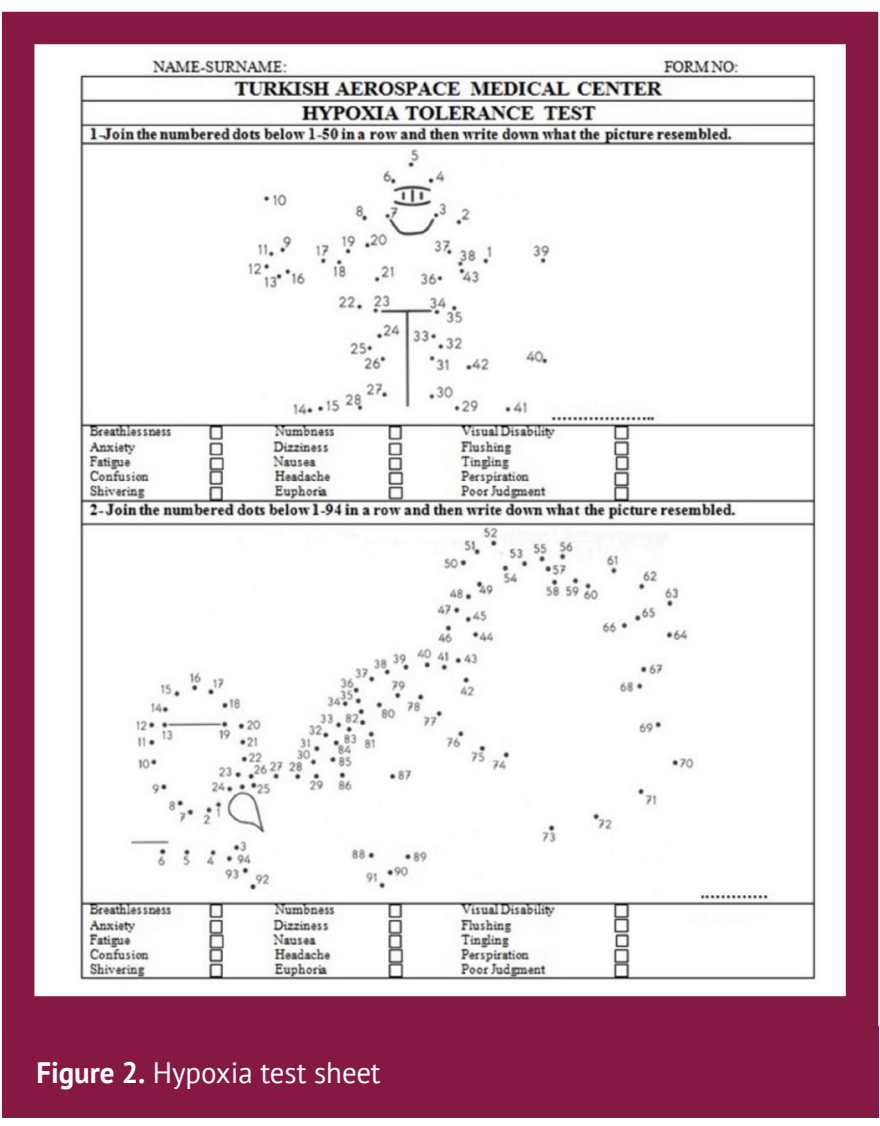


Also, frequently reported symptoms in Non-SMK participants were anxiety, shivering, perspiration, numbness and tingling at the late phase. Both early and late symptoms among pilots were higher in SMK group ( $p>0.05$ ). Flushing was the most frequent symptom in SMK group and numbness was the most frequent symptom in Non-SMK group (Table 2).

\section{Discussion}

Many chemicals, which are considered to be toxic and carcinogenic, are released during the combustion of tobacco. The best known of these substances are tar and carbon

\section{Table 1. Study results according to smoking status.}

\begin{tabular}{|c|c|c|c|c|c|}
\hline \multirow{2}{*}{ Variables } & \multirow{2}{*}{$\mathrm{n}$} & SMK & \multirow{2}{*}{$n$} & Non-SMK & \multirow{2}{*}{ p } \\
\hline & & Mean \pm SD & & Mean \pm SD & \\
\hline Age & \multirow{4}{*}{25} & $22.40 \pm 0.6$ & \multirow{4}{*}{53} & $22.58 \pm 0.6$ & $0.19^{* *}$ \\
\hline BMI & & $22.99 \pm 1.8$ & & $22.63 \pm 1.9$ & $0.43^{*}$ \\
\hline $\mathrm{Hb}$ & & $14.88 \pm 1.0$ & & $14.80 \pm 0.7$ & $0.69^{*}$ \\
\hline $\mathrm{Htc}$ & & $45.46 \pm 2.6$ & & $45.48 \pm 2.4$ & $0.97^{*}$ \\
\hline PreTrP $\left(\mathrm{SpO}_{2}\right)$ & 21 & $98.43 \pm 1.1$ & 47 & $98.7 \pm 1.0$ & $0.36^{* *}$ \\
\hline $\operatorname{AltP}\left(\mathrm{SpO}_{2}\right)$ & \multirow{2}{*}{25} & $99.44 \pm 2.2$ & \multirow{2}{*}{53} & $99.79 \pm 0.8$ & $0.57^{* *}$ \\
\hline $\mathrm{HypP}\left(\mathrm{SpO}_{2}\right)$ & & $65.32 \pm 6.6$ & & $66.11 \pm 5.8$ & $0.49^{* *}$ \\
\hline
\end{tabular}

SMK: Smokers' Group, Non-SMK: Non-Smokers' Group. ${ }^{*}$ Independent sample t-test **Mann-Whitney U test BMI: Body mass index, hb: Hemoglobin, Htc: Hydrothermal carbonization

Table 2. Frequencies and percentage of the Hypoxia symptoms according to smoking status

\begin{tabular}{|c|c|c|c|c|c|c|c|c|c|c|c|c|c|c|c|c|c|c|}
\hline \multirow{4}{*}{$S / N$} & \multirow{4}{*}{$\begin{array}{l}\text { HYPOXIA } \\
\text { SYMPTOMS }\end{array}$} & \multicolumn{8}{|c|}{ SMK } & \multicolumn{8}{|c|}{ NON-SMK } & \multirow{4}{*}{$\begin{array}{l}\text { All } \\
\text { Total } \\
\text { Within } \\
\text { Symptoms } \\
\text { n }\end{array}$} \\
\hline & & \multicolumn{3}{|c|}{ Early } & \multicolumn{3}{|c|}{ Late } & \multirow{2}{*}{\multicolumn{2}{|c|}{$\begin{array}{l}\text { Total } \\
\text { Within } \\
\text { Symptoms }\end{array}$}} & \multicolumn{3}{|c|}{ Early } & \multicolumn{3}{|c|}{ Late } & \multirow{2}{*}{\multicolumn{2}{|c|}{$\begin{array}{l}\text { Total } \\
\text { Within } \\
\text { Symptoms }\end{array}$}} & \\
\hline & & \multicolumn{2}{|c|}{$\begin{array}{l}\text { Within } \\
\text { Symptoms }\end{array}$} & \multirow{2}{*}{\begin{tabular}{|l} 
SMK \\
Pilots \\
$\mathrm{N}=25$
\end{tabular}} & \multicolumn{2}{|c|}{$\begin{array}{l}\text { Within } \\
\text { Symptoms }\end{array}$} & \multirow{2}{*}{ 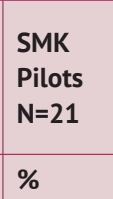 } & & & \multicolumn{2}{|c|}{$\begin{array}{l}\text { Within } \\
\text { Symptoms }\end{array}$} & \multirow{2}{*}{$\begin{array}{l}\text { Non } \\
\text { SMK } \\
\text { Pilots } \\
\mathrm{N}=53 \\
\%\end{array}$} & \multicolumn{2}{|c|}{$\begin{array}{l}\text { Within } \\
\text { Symptoms }\end{array}$} & \multirow{2}{*}{\begin{tabular}{|l|} 
Non \\
SMK \\
Pilots \\
N=48 \\
$\%$ \\
\end{tabular}} & & & \\
\hline & & $\mathrm{n}$ & $\%$ & & $\mathbf{n}$ & $\%$ & & $\mathrm{n}$ & $\%$ & $\mathrm{n}$ & $\%$ & & $n$ & $\%$ & & $\mathbf{n}$ & $\%$ & \\
\hline 1 & Breathlessness & 0 & 0 & 0 & 3 & 5.45 & 14.29 & 3 & 3.85 & 3 & 5 & 5.66 & 4 & 4.30 & 8.33 & 5 & 3.94 & 8 \\
\hline 2 & Anxiety & 1 & 3.23 & 4 & 4 & 7.27 & 19.05 & 4 & 5.13 & 4 & 6.67 & 7.55 & 7 & 7.53 & 14.58 & 8 & 6.30 & 12 \\
\hline 3 & Fatigue & 2 & 6.45 & 8 & 4 & 7.27 & 19.05 & 5 & 6.41 & 2 & 3.33 & 3.77 & 6 & 6.45 & 12.5 & 7 & 5.51 & 12 \\
\hline 4 & Confused & 1 & 3.23 & 4 & 3 & 5.45 & 14.29 & 4 & 5.13 & 4 & 6.67 & 7.55 & 5 & 5.38 & 10.42 & 7 & 5.51 & 11 \\
\hline 5 & Shivering & 0 & 0 & 0 & 2 & 3.64 & 9.52 & 2 & 2.56 & 6 & 10 & 11.32 & 7 & 7.53 & 14.58 & 10 & 7.87 & 12 \\
\hline 6 & Numbness & 3 & 9.68 & 12 & 7 & 12.73 & 33.33 & 9 & 11.54 & 7 & 11.67 & 13.21 & 24 & 25.81 & 50 & 28 & 22.05 & 37 \\
\hline 7 & Dizziness & 2 & 6.45 & 8 & 6 & 10.91 & 28.57 & 8 & 10.26 & 7 & 11.67 & 13.21 & 5 & 5.38 & 10.42 & 9 & 7.09 & 17 \\
\hline 8 & Nausea & 2 & 6.45 & 8 & 3 & 5.45 & 14.29 & 4 & 5.13 & 2 & 3.33 & 3.77 & 4 & 4.30 & 8.33 & 4 & 3.15 & 8 \\
\hline 9 & Headache & 3 & 9.68 & 12 & 0 & 0 & 0 & 3 & 3.85 & 3 & 5 & 5.66 & 2 & 2.15 & 4.17 & 4 & 3.15 & 7 \\
\hline 10 & Euphoria & 0 & 0 & 0 & 0 & 0 & 0 & 0 & 0 & 0 & 0 & 0 & 0 & 0 & 0 & 0 & 0 & 0 \\
\hline 11 & $\begin{array}{l}\text { Visual } \\
\text { Disturbances }\end{array}$ & 3 & 9.68 & 12 & 3 & 5.45 & 14.29 & 6 & 7.69 & 2 & 3.33 & 3.77 & 5 & 5.38 & 10.42 & 6 & 4.72 & 12 \\
\hline 12 & Flushing & 6 & 19.35 & 24 & 6 & 10.91 & 28.57 & 9 & 11.54 & 5 & 8.33 & 9.43 & 6 & 6.45 & 12.5 & 10 & 7.87 & 19 \\
\hline 13 & Tingling & 2 & 6.45 & 8 & 6 & 10.91 & 28.57 & 8 & 10.26 & 7 & 11.67 & 13.21 & 8 & 8.60 & 16.67 & 13 & 10.24 & 21 \\
\hline 14 & Perspiration & 4 & 12.9 & 16 & 5 & 9.09 & 23.81 & 9 & 11.54 & 7 & 11.67 & 13.21 & 7 & 7.53 & 14.58 & 12 & 9.45 & 21 \\
\hline 15 & Poor Judgment & 2 & 6.45 & 8 & 3 & 5.45 & 14.29 & 4 & 5.13 & 1 & 1.67 & 1.89 & 3 & 3.23 & 6.25 & 4 & 3.15 & 8 \\
\hline & TOTAL & 31 & 100 & 52 & 55 & 100 & 76.2 & 78 & 100 & 60 & 100 & 39.6 & 93 & 100 & 70.8 & 127 & 100 & 205 \\
\hline & & & $p$ & $0.336^{*}$ & & & $0.774^{* *}$ & & & & & $0.336^{*}$ & & & $0.774^{* *}$ & & & \\
\hline
\end{tabular}


monoxide. Carbon monoxide (CO) that presents in cigarettes leads to oxygen deficiency in cells in two ways. Firstly, CO has 250 times greater affinity to hemoglobin than $\mathrm{O}_{2}$ and smoking reduces oxyhemoglobin rate while increasing carboxyhemoglobin rate in the blood. Secondly, it has directly toxic effects on the tissue cells. Even very low levels of CO pressure like $0.6 \mathrm{mmHg}$ in the air can be fatal (3). Smoking may cause anemic hypoxia and aggravate hypoxia symptoms (4).

Smoking is the leading cause of many different health issues within society. The World Health Organization states that many types of cancers, heart diseases, and lung diseases have been associated with smoking. More than 7 million people die from tobacco related diseases in each year (5). In 2020 , a total of $31.2 \%$ of adults (approximately 16 million) aged 15 years and older were currently smoking in Turkey. Prevalence was higher among men (47.9\%) than women (15.2\%). Approximately 12 million men and 4 million women smoked tobacco. (6). The use of tobacco products among aviation personnel is similar to that of the normal population (7). In addition, it was reported that smoking was also the risk factor for cardiovascular diseases in a study conducted on commercial pilots (8).

Deussing et al. (9) administered a survey to naval aviators and of the 566 aviators who completed the survey before the aviation physiology training, 112 (20\%) reported experiencing hypoxia symptoms in a tactical jet aircraft and 64 aviators (57\%) indicated that they were not wearing the required oxygen mask when the incident first occurred. Cable GG executed a study in "Australian All Aircraft Safety Occurrence Reports" data base for investigation of hypoxia as a factor between 1990 and 2001. During this period, 27 reports of hypoxia were filed, involving 29 aircrew. Consciousness was lost in only two cases, and one of these resulted in a fatal accident. Most incidents (85.1\%) occurred in fighter or training aircraft with aircrew who used oxygen equipment routinely (10). Hypoxia has long been recognized as a significant physiological threat at altitude and flight mishaps can be attributable to hypoxia. Regarding this, "Hypoxia Familiarization Training" remains a vital component of aircrew trainings.

Yoneda et al. (11) conducted a study in 152 nonsmoking males who were divided into 2 groups as juniors and seniors. The mean age of juniors group was $26.8 \pm 0.5$ years and the mean hypoxic saturation rate of them was reported as $58.4 \%$ \pm 0.9 (11). Our Non-SMK groups resembles the Yoneda's junior group, but all subjects of our study were younger than Yoneda's junior group ( $22.58 \pm 0.6$ years vs. $26.8 \pm 0.5$ years) and hypoxic saturation rates were higher in our study $(66.11 \%$ \pm 5.8 vs. $58.4 \% \pm 0.9$ ).

Smoking may decrease hypoxia tolerance and may have negative effects on the safe operation of the aircraft. In this aspect, we investigated the effect of smoking (Carbon Monoxide) on the oxyhemoglobin saturation in this study. There were no statistically significant differences detected in PreTrP, AltP and HypP parameters between SMK and NonSMK groups. All three-oxygen saturation means of Non-SMK subjects were slightly higher than those of SMK, but these differences were not statistically significant $(p>0.05)$. These results may be resulted from a negative effect of Carbon Monoxide (CO) due to chronic cigarette smoking. We have also considered that the absence of statistical significance between these two groups might have been caused by the low number of the subjects and 30,000 feet very high study altitude. At these altitudes, saturation of the oxyhemoglobins known to be reduced to the level of $60 \%$ and the characteristics of unsaturated hemoglobin dissociation curve may give rise to this result.

In Deussing et al. (9) study, the three most common recorded in-flight hypoxia symptoms were tingling (54\%), difficulty in concentrating (32\%), and dizziness (30\%). In Cable GG's study, the most common reported symptoms were cognitive impairment, dizziness/lightheadedness, paresthesia and unwellness (non-specific) (10). In Yoneda et al. (11) study, flushing and thinking impairment were the most frequently observed symptoms (more than $80 \%$ ), while nausea and euphoria were the least common (less than $10 \%)$. On the other hand, in our study, we also address the subjective symptoms that may appear in hypoxic environment of aviation. Also, in this study, the three most common symptoms for all participants were numbness, tingling and perspiration and the least common reported symptom was euphoria in our study. Our results were concordant with published literature.

Yoneda et al. (11) executed another study on 590 nonsmokers and 582 smokers. The mean age of Non-SMK and SMK were $33.5 \pm 9.9$ years and $33.2 \pm 9.2$ years, respectively. Subjects were asked to fill out the questionnaire concerning the symptoms that they felt during hypoxia after the completion of the training. The intensity of subjective symptoms during hypoxia was placed in the rank order. The order is almost the same for both groups. Non-smokers showed significantly sensitive responses to the five symptoms of thinking impairment, visual impairment, fatigue, dyspnea, and tremor (12). The participants experience transient amnesia during altitude hypoxia but in Yoneda's 1997 study, survey was completed after full recovery from hypoxia. We considered this was a limitation for Yoneda's study. However, in our study, 2 surveys were filled out during hypoxia to exclude phenomena of the hypoxic amnesia. Flushing was the most frequent symptom in SMK group, numbness was the most frequent symptom in Non-SMK group in present study. In contrast to the Yoneda's study, more symptoms were checked among SMK subjects for both in early and late phases of hypoxia in this study. This 
might be attributed to hypoxia sensitiveness of SMK subjects. We considered that this situation could be considered as a disadvantage of smokers in aviation environment.

\section{Conclusion}

In response to the efforts of many anti-smoking organizations, several states and local governments have passed ordinances to restrict smoking in many public places, putting warning labels on tobacco packaging, collecting more tobacco taxes, and banning on advertising, promotion, and sponsorship for tobacco products (13). Antismoking efforts also put in aviation sector. The ICAO approved to prohibit smoking on international commercial flights by the $1^{\text {st }}$ of July 1996. Too many airlines and governments have proposed a rule that would extend the prohibition of cigarette smoking in all commercial flights (14). On the other hand, the use of tobacco products in aviation personnel is similar to that of the normal population. Because of this, doctors who carry out aviation examinations and practise preventive medicine in aviation field should be aware of the importance of this issue and well know the tobacco cessation treatment (7).

Because of the technical difficulties and standard training procedures, we performed this study at 30,000 feet altitude. We have considered that statistically significant results may have been gained if this study would have been redone at 18,000 and 25,000 simulated altitudes. In these altitudes, oxygen saturation would be higher and the influences of carboxyhemoglobin on hypoxia tolerance could be better observed.

\section{Ethics}

Ethics Committee Approval: Ethics committee approval was received from Gülhane Military Medical Academy Command (number: 1491-1268-11/1539, date: 21/02/2011).

Informed Consent: Patients gave written informed consent before the study procedures.

Peer-review: Externally and internally peer-reviewed.

\section{Authorship Contributions}

Concept: E.E., M.Ş.I., C.T., Design: E.E., M.Ş.I., C.T., Data Collection or Processing: E.E., M.Ş.I., C.T., Analysis or Interpretation: E.E., M.S.I., C.T., Literature Search: E.E., M.Ş.I., C.T., Writing: E.E., M.Ş.I., C.T.

Conflict of Interest: No conflict of interest was declared by the authors.
Financial Disclosure: The authors declared that this study received no financial support.

\section{References}

1. Oxford RR, Warren S. Silberman WS. Pilot health and aeromedical certification. In: David JR, Johnson R, Stepanek J, Fogarty JA, editors. Fundamentals of aerospace medicine. $4^{\text {th }}$ ed. Philadelphia: Lippincott Williams \& Wilkins; 2008:283. [Crossref]

2. Duncan, John S. "Pilot's handbook of aeronautical knowledge." US Department of Transportation. Federal Aviation Administration. Flight Standards Service. United States Department of Transporation (2016). [Crossref]

3. Transport of oxygen and carbon dioxide in blood and tissue fluids. In: Hall JE, Guyton AC, editors. Guyton and hall textbook of medical physiology. 13th ed. Philadelphia: Elsevier; 2016:534. [Crossref]

4. Gradwell DP. Hypoxia and hyperventilation. In: Gradwell DP, Rainford DJ, editors. Ernsting's aviation and space medicin. $5^{\text {th }}$ ed. New York: Taylor \& Francis Group, LLC; 2016:49. [Crossref]

5. World Health Organization. Geneva: Tobacco: Leading cause of death, illness, and impoverishment. c2020 Last Accessed Date: 02.03.2021. Available from: https://www.who.int/news-room/fact-sheets/detail/ tobacco. [Crossref]

6. The Ministry of Heath of Turkey [Internet]. Ankara: Global Adult Tobacco Survey (GATS), Turkey-2020, P:11 c2020 Last Accessed Date: 02.03.2021. Available from: https://havanikoru.saglik.gov.tr/dosya/dokumanlar/ yayinlar/GATS-Turkey-2010-ENG.pdf [Crossref]

7. Grossman A, Landau D-A, Barenboim E, Goldstein L. Smoking cessation therapy, and the return of aviators to flying duty. Aviat Space Environ Med. 2005;76:1064-1067. [Crossref]

8. Houston S, Mitchell S, Evans S. Application of a cardiovascular disease risk prediction model among commercial pilots. Aviat Space Environ Med. 2010;81:768-773. [Crossref]

9. Deussing EC, Artino JR AR, Folga RV. In-flight hypoxia events in tactical jet aviation: characteristics compared to normobaric training. Aviat Space Environ Med. 2011;82:775-781. [Crossref]

10. Cable GG. In-flight hypoxia incidents in military aircraft: Causes and implications for training. Aviat Space Environ Med. 2003;74:169-172. [Crossref]

11. Yoneda I, Tomoda M, Tokumaru O, Sato T, Watanabe Y. Time of useful consciousness determination in aircrew members with reference to prior altitude chamber experience and age. Aviat Space Environ Med. 2000;71:72-76. [Crossref]

12. Yoneda I, Watanabe Y. Comparisons of altitude tolerance and hypoxia symptoms between non-smokers and habitual smokers. Aviat Space Environ Med. 1997;68:807-811. [Crossref]

13. World Health Organization [Internet]. Geneva: WHO Report on the Global Tobacco Epidemic, 2015. C2015 Last Accessed Date: 02.03.2021. Available from: https://apps.who.int/iris/ bitstream/handle/10665/178574/9789240694606 eng. pdf;jsessionid $=3453220$ CD4F0C79C821D89A62E9FF2C1? sequence $=1$ [Crossref]

14. Holm AL, Davis RM. Clearing the airways: advocacy and regulation for smoke free airlines. Tob Control. 2004;13(Suppl 1):i30-i36. [Crossref] 